\title{
Development Strategy for the Tanjung Palette Tourism Area, Bone Regency
}

\author{
Indah Anugrah Supardi ${ }^{1}$, Wahyu Nurdiansyah Nurdin ${ }^{2}$ \\ ${ }^{1}$ Makassar Tourism Polytechnic, Indonesia \\ ${ }^{2}$ College of Administrative Sciences, Makassar State Administration Institute, Indonesia, \\ Indonesia
}

Received: September 15, 2020

Revised: September 24, 2020

Accepted: September 26, 2020

\begin{abstract}
This study aims to discusses abpout the development strategy for the Tanjung Palette Tourism Area This study used a qualitative approach using the Kearns SWOT matrix. The result of the study The Tanjung Palette tourism area certainly has a very complex environment in it. Especially the cultural climate that local people with foreign cultures enter through foreign tourists. Therefore, environmental management, both physical and cultural, must be an important concern for all interested parties. Development of Tourist Market Share The development of tourist market share is an effort to identify the wants / needs of tourism consumers, determine the products offered, determine prices, promote, and research tourism market share.
\end{abstract}

Keywords: Development Strategy, Cultural Climate, SWOT

\section{Introduction}

In the era of the Industrial Revolution 4.0 that hit the entire world, of course, it requires all parties to improve themselves in facing challenges as well as threats to the joints of social, economic and cultural life. The role of the government as the state administrator must be very swift in designing policy formulations that can have positive implications for the state structure. This can be done by creating opportunities as a strategy in dealing with these challenges based on the potential that is owned to gain profits. Indonesia as the largest archipelagic country in the world with a population of 230 million people is certainly very rich in potential and resources, so that the government has a big responsibility in managing and developing it so that it is effective in increasing and increasing state treasury revenues.

One of the potentials that must be developed by the government in relation to increasing global competitiveness is the potential for tourism in Indonesia. We all know that the development of tourism today has attracted the attention of people (tourists) both from within the country and abroad. So that this is one of the government's concerns in designing policies related to regional development which are packaged in general tourism development. In fact, according to Spillane (1987), the role of tourism in state development is broadly based on three aspects, namely the economic side (sources of foreign exchange, taxes), the social aspect (job creation), and the cultural aspect (introducing our culture to tourists foreign).

Tourism has now become one of the new styles of industry, which is able to provide rapid economic growth in terms of employment opportunities, income, standard of living and in activating other production sectors in tourist-receiving countries (Wahab, 2003; Amiruddin, 2020). Therefore, tourism is one of the important things for a country. With the existence of tourism, a country or more specifically the local government where the tourist attraction is located, will get income from the income of each tourist attraction (Cohen, 2002; Richards, 2002; Boniface, 2013). Tourism is also a commodity that is needed by every individual. The 
reason is because traveling activities for an individual can increase creative power, eliminate boredom, relaxation, shopping, business, knowing the historical and cultural heritage of a certain ethnicity, health and spiritualism tourism. With the increase in free time as a result of shorter working days and supported by increased income, tourism activities will increase (Yuwana, 2010).

Bone Regency as one of the districts in South Sulawesi, Indonesia is certainly one of the areas most attractive to local and foreign tourists. This is based on the potential possessed by the region as "Bumi Arung Palakka" with its rich culture and quite diverse tourism potential. Bone Regency has a geographical location consisting of mountainous and coastal areas so that it has various ethnicities, cultures and other tourist objects, making it interesting to visit both nationally and internationally.

One of the most captivating tourist attractions is the Tanjung Pallette tourist area which offers beautiful corals with stunning beach panoramas. This Tanjung Pallette tourist object is the most favorite tourist location in Bone. At Cape Pallette, the sea view is so charming and the air is very fresh. In addition, at the Tanjung Pallette tourist location, there is also a water park or waterboom which is in the same location. The location of Tanjung Pallette is in Palette Village, East Tanete Riattang District, Kab. Bone.

Tanjung Pallette as a tourist attraction has become a pillar that supports the economy of the Bone region, especially in the tourism sector in general, which has attracted large numbers of tourists. This assumption is based on the following data which illustrates the increase in the number of tourists visiting Bone district in the past five years.

From the data from the Bone Regency Government Service (2019) it can be seen that the number of tourist visits to Bone Regency from year to year has increased over the past five years. In 2015 the number of tourist visits reached 32,938 people, then increased in 2016 to reach 50,015 people. Furthermore, in 2017 there were 59,520 tourist visits and an increase of 65,333 people in 2018. Meanwhile in 2019 the total number of foreign and domestic tourist visits reached 80,239 people. This certainly proves that the tourism potential in Bone Regency, especially in the Tanjung Pallette tourist attraction, is progressing.

Local governments need to think about a tourism strategy considering that the Tanjung Pallette tourist area has enormous potential in growing the regional economy. In addition, the big name of the Tanjung Pallette tourist attraction at the national to international levels should be a big consideration by the local government to further develop it so that it can attract more tourists. The solutions referred to in this case are planning and formulating strategies by the local government related to the development of the Tanjung Pallette tourist area so that it can be more competitive in attracting tourists. Planning and formulating strategies as a form of efforts made by the government to create and conserve tourist areas using various approaches in order to identify strengths, weaknesses, opportunities and threats. Thus, the government, in this case the Bone Regency Tourism Office, can take strategic steps from the various available options.

Strategy is very important for the development of an organization/company in order to achieve goals, both short-term goals and long-term goals. Analysis in strategy development is based on internal and external environmental observations in determining strategy formulation, then entering the implementation stage to evaluation. Therefore, strategy formulation is a tactical step that is systematic in achieving organizational goals. The purpose of this study was to determine the strategy for developing the tourist area of Tanjung Pallette, Bone Regency. 


\section{Methods}

This study used a qualitative approach using the Kearns SWOT matrix. The object or location of this research is the Tanjung Pallette tourist area as one of the most famous tourist objects in Bone Regency. The focus of the research is the concentration of concentration on the research objectives to be carried out so that it must be explicitly disclosed to make it easier for researchers before making observations. The focus of this research is to analyze the strategy for developing the tourism area of Bone Regency (Tanjung Pallette Tourism Area) using the Qualitative SWOT Analysis model according to Kearns.

The data analysis unit in this research is related organizations / institutions based on objective considerations to describe research on the strategy for developing tourism areas in Bone Regency. In this case the unit of analysis is the Tanjung Pallette tourism area in Bone Regency. The resource persons in this study were the Head of the Bone Regency Tourism Office, the Head of the Sub Division of General Affairs and Personnel of the Bone Regency Tourism Office, the Head of the Tourism Destination Development Division of the Bone Regency Tourism Office, the Head of the Creative Economy Development Section of the Bone Regency Tourism Office, the Manager of the Tanjung Palette Tourism Area. Then data collection in this study was carried out directly through observation and interviews. Data analysis activities are carried out through Data Reduction, Data Display and Conclusion Drawing / Verification.

\section{Result and Discussion}

The Tanjung Palette tourism area certainly has a very complex environment in it. Especially the cultural climate that local people with foreign cultures enter through foreign tourists. Therefore, environmental management, both physical and cultural, must be an important concern for all interested parties. The local government as the person in charge of the development of the Tanjung Palette area must take tactical steps in analyzing the environment. According to the head of the Bone Regency Tourism Office, the Tanjung Palette tourism environment or area in general is divided into $70 \%$ community ownership and $30 \%$ government ownership. This gives an indication of the environmental management and the Tanjung Palette area which is still dominated by local people.

In addition, from the cultural side, the community still has a traditional paradigm of the demands for area development by assuming that land and buildings located in the tourist area are their ownership, so that their management and arrangement is based on the rights of the community concerned. This is in accordance with the statement of the Head of the Bone Regency Tourism Office that one of the obstacles faced by the government in developing the Tanjung Palette area is that people are still not ready to accept policies or actions by the Bone Regency Tourism Office. Thus a new conflict arises between the government and the community regarding the development and arrangement of tourist areas.

Furthermore, the strategic issues raised by Mr. Budiono (Head of the Bone Regency Tourism Office) regarding three main focuses were used as guidelines in the development of Tanjung Palette tourism. These three things are security, cleanliness and comfort which are still in the process of making them happen. Regarding security at the location, it is quite controlled with the presence of the police on duty, although it is still limited in number.

SWOT analysis provides a "basic view" of the analysis of the conditions at hand so that the right strategy can be obtained in order to achieve a certain goal (Karppi et al., 2001; Andersen, 2013; Maté et al., 2015). The SWOT analysis describes in detail the aspects that are the strengths, weaknesses, opportunities, and threats of the Tanjung Palette district tourism development plan. 
The factors that become threats and obstacles to the development of the Tanjung Palette tourism area at this time are the social environment of the local community who is not ready to face the demands of development. According to the Head of the Bone Regency Tourism Office, this was based on a technical comparison of environmental management in the Tanjung Palette tourism area between the government (30\%) and the community (70\%). Thus, environmental management in the area is technically still dominated by the local community, so that it becomes a challenge as well as an obstacle in the development of the Tanjung Palette tourism area going forward.

The internal analysis that the researchers have done is more directed at the weaknesses of the regional government of the Bone Regency Tourism Office in the field of human resources. The results of the statement by the Head of the Tourism Office stated that one of the obstacles faced by the Tourism Office today is in terms of human resource capacity. So, according to him, it is necessary to provide education and training for the staff of the Tourism Office, especially in the tourism sector, so that they will better understand and understand the importance of tourism development in supporting regional development independently.

From the research conducted by the author on the internal and external analysis of the Tanjung Palette tourism, the authors get the following results.

\section{Strength}

Strengths are situations and internal capabilities that are positive, which allow the organization to have a strategic advantage in achieving its goals. What can be highlighted as a strength is that visitors can enjoy many things in the Cape Palette area. In addition to the beach view from the edge of the cliff, visitors can also enjoy the swimming pool and various water rides that are in the Tanjung Palette Tourism Area. Visitors will also be given facilities and infrastructure such as a gazebo and lodging is provided for visitors who will stay at the place. Visitors are also provided with a place to change clothes, to change their wet clothes after enjoying various Water Games. Based on the results of interviews conducted by the author, the strengths of Tanjung Palette Regency in tourism are as follows: (1) Strategic Location of Tanjung Palette Tourism Area, (2) Area of Tanjung Palette Tourism Area, (3) Tanjung Palette Area which has the potential to be developed (4) Within a tourism area, there are many types of water rides. In developing tourism in Tanjung Palette, an important thing that is important for the government to do is asset management or partnerships as described above, so that it can support a comfortable tourism climate.

\section{Weakneses}

Weakness is a condition of weakness in an existing organization, project or business concept. The weakness that is analyzed is a factor that is contained in the body of the organization, project or business concept itself. Based on the results of interviews and data collected, the authors explain that the weaknesses of the Bone Regency Tourism Office in the development of the Tanjung Palette Tourism Area are as follows: (1) Inadequate facilities and mobility, (2) Lack of training to create management personnel for the Tanjung Palette tourism area reliable, quality, professional and disciplined, (3) Low interest and public awareness to preserve and develop local tourism which has the potential to promote tourism as well as to increase community income. (4) Community empowerment is inadequate, (5) Cooperation with tourism business service actors is not yet effective, (6) Facilities and infrastructure for tourism objects are still inadequate. 


\section{Opportunity}

Opportunities are conditions for future development opportunities that occur. Conditions that occur are opportunities from outside the organization, project or business concept itself. For example competitors, government policies and environmental conditions.

The opportunities that the Bone Regency Tourism Office has in developing the Tanjung Palette Tourism area are as follows: (1) The priority for the development of the Tanjung Palette Pariwisa Area is contained in the Bone District Strategic Plan, (2) Various potential tourist attractions that can be developed in the Tanjung Palette Tourism Area, (3) The number of investors and outsiders who need data on tourism potential, (4) The security and comfort situation around the Tanjung Palette area is very conducive, (5) The rapid development of mass media and technology as a means of supporting tourism in Tanjung Palette.

\section{Threats}

Threats are conditions that threaten from outside. These threats can disrupt the organization, project or business concept itself. Based on the results of the interview the authors analyzed the various threats to the development of the Tanjung Palette Tourism Area as follows: (1) The central government program has not been optimal in optimizing and realizing the development of Tanjung Palette tourism, (2) The management of regional resource potential in the tourism sector has not been optimal, (3) ) There is very little investment interest in the tourism sector, especially during the pandemic, (4) The rapid development and development of tourism outside Bone regency has resulted in a higher level of competition.

After seeing the strengths, weaknesses, opportunities and threats, the steps taken by the Bone Regency tourism office to develop the Tanjung Palette Tourism Area are:

\section{The Power to Take Advantage of Opportunities}

The strategy in using strength to take advantage of opportunities is to motivate the human resources who are owned with a high commitment to provide or prepare the data needed by investors. Increasing the ability of human resources to manage data in supporting data in the tourism sector. Utilizing existing funds to support better and more targeted data presentation in the field of tourism.

\section{The Power to Avoid Threats}

The strategy in using strength to avoid threats is to increase the ability of human resources to have a high commitment to be able to obtain accurate data. Improve the quality of human resources who are committed to facing competition in the information age and free market. Maximizing budget for management. Developing and utilizing good human resources, so as to support the smooth management of the tourism sector and sub-regional and regional cooperation. Proactively improve the quality and completeness of data by visiting hard-toreach areas and validating all incoming data

\section{Reducing Weakness to Pursue Opportunities}

The strategy in reducing weaknesses to pursue opportunities is to improve the quality of human resources by attending training courses. Improve the quality of human resources for the management of tourist objects. Improve facilities and infrastructure to be able to improve the quality of the Tanjung Palette Tourism Location. The effectiveness of coordination or consultation with tourism business actors and related agencies or institutions. 


\section{Reducing Weakness to Avoid Threats}

The strategy in reducing weaknesses to avoid threats is to provide internal guidance so that existing human resources carry out their duties and functions optimally. Improve coordination to get complete and accurate data. Improve performance to obtain tourism data. Efforts to increase / increase operational funds through APBD. Increase cooperation with tourism business actors through meetings and socialization of programs and activities.

Table 6. SWOT Matrix for the Development of the Tanjung Palette Tourism Area

\begin{tabular}{|c|c|c|}
\hline & Strength (S) & Wea \\
\hline xtern & $\begin{array}{l}\text { - Tanjung Palette area that has } \\
\text { the potential to be developed } \\
\text { - High leader support } \\
\text { - Sufficient number of } \\
\text { personnel }\end{array}$ & $\begin{array}{l}\text { - The facilities and mobility } \\
\text { of tourist sites are still } \\
\text { lacking } \\
\text { - Very limited budget } \\
\text { - Lack of experience in } \\
\text { existing human resources }\end{array}$ \\
\hline Opportunity (O) & & \\
\hline $\begin{array}{l}\text { - Many investors from } \\
\text { outside parties need } \\
\text { data on tourism } \\
\text { potential } \\
\text { - The situation of } \\
\text { security and comfort } \\
\text { in the tourist location } \\
\text { area in particular and } \\
\text { in Bone Regency in } \\
\text { general } \\
\text { - The rapid } \\
\text { development of the } \\
\text { mass media as a } \\
\text { means of promoting } \\
\text { tourism }\end{array}$ & $\begin{array}{l}\text { - Make use of statutory } \\
\text { regulations such as making } \\
\text { a regional regulation or a } \\
\text { regional regulation } \\
\text { (Perbup) to attract investors } \\
\text { in developing the Tanjung } \\
\text { Palette tourism area } \\
\text { - Motivate committed } \\
\text { personnel to prepare the } \\
\text { data required by investors } \\
\text { - Increasing the capacity of } \\
\text { data management } \\
\text { personnel in supporting the } \\
\text { tourism sector }\end{array}$ & $\begin{array}{l}\text { - Improve the quality of } \\
\text { existing human resources } \\
\text { by following training and } \\
\text { training } \\
\text { - Improve the quality of } \\
\text { human resources for } \\
\text { tourism } \\
\text { management } \\
\text { - Improve facilities and } \\
\text { infrastructure to improve } \\
\text { the quality of the Tanjung } \\
\text { Palette Tourism Location }\end{array}$ \\
\hline Threat (T) & & \\
\hline $\begin{array}{l}\text { - Not yet optimal in } \\
\text { realizing tourism } \\
\text { development in the } \\
\text { Tanjung Palette area } \\
\text { - There is very little } \\
\text { investment interest in } \\
\text { tourism } \\
\text { - The rapid } \\
\text { development of } \\
\text { tourism development } \\
\text { and development } \\
\text { outside Bone } \\
\text { Regency }\end{array}$ & $\begin{array}{l}\text { personnel owned so that they } \\
\text { have a high commitment to } \\
\text { be able to obtain accurate } \\
\text { tourism data } \\
\text { - Improve the quality of } \\
\text { human resources who are } \\
\text { committed to facing } \\
\text { competition in the free } \\
\text { market information age } \\
\text { - Improve coordination to get } \\
\text { complete and accurate data. }\end{array}$ & $\begin{array}{l}\text { - Attempt to increase } \\
\text { operational funds through } \\
\text { the APBD } \\
\text { - Increase cooperation with } \\
\text { tourism business actors } \\
\text { through meetings and } \\
\text { socialization of programs } \\
\text { and activities. } \\
\text { - Carry out internal } \\
\text { coaching so that existing } \\
\text { human resources carry out } \\
\text { their duties and functions } \\
\text { optimally }\end{array}$ \\
\hline
\end{tabular}

Source: Primary Data, 2020 
Based on the SWOT analysis above, several key success factors can be identified that serve to focus more on organizational strategy in order to achieve organizational goals and missions effectively and efficiently.

By considering these strategies, 7 (seven) success factors were obtained which were the determining factors for the success of the tourism office in tourism development in Tanjung Palette, namely developing a valid data base in the tourism sector as well as regional potential to attract investors. Developing aspirational and innovative tourism data. Develop easy access to information from all regional apparatus organizations and the presentation of effective reporting. Proactively improve the quality and completeness of data by always updating the progress of the tourism area in Tanjung Palette. Improve the quality of existing human resources through education and training. Improve facilities and infrastructure in the Tanjung Palette area.

The Tourism Office as an institution led by a head of the service and within the area of the regional head's authority in carrying out development in his area certainly has several objectives. One of the goals is to improve the welfare of the community through tourism development with the goal of increasing the number of tourism destination arrangements with a regional approach sector. Increase the capacity of tourism actors

In the strategic plan of the Bone Regency Tourism Office, it explains several inhibiting factors (weaknesses / threats), namely the situation and internal inability that affect the service problems of the Bone Regency Tourism Office including limited investment in tourism in the development of large-scale tourist attractions (DTW). Lack of facilities and infrastructure to support the development of the institutional vision and mission. Lack of data and information available as support and analysis material in the tourism planning process by both the tourism office and other DPOs. There is still a lack of cooperation with other Kemitraan institutions in the tourism sector as input to the Tanjung Palette district government. Limited quality of competent tourism human resources. Lack of coordination and synergy between tourism institutions and across sectors that have not been effective. Industry development and tourism partnerships have not been optimal. The development of tourism marketing has not been optimal in the tourism marketing information system.

The driving factors (strengths/opportunities) that affect the problems of Tanjung Palette Tourism Development, namely the existence of human resources who are mostly highly educated (general education) so that they have a far future vision and are highly dedicated in completing their duties. There is support from the regent and deputy regent for tourism development in development planning according to the vision and mission of Bone regency. The existence of public concern about tourism. Unique geographical and cultural conditions are very supportive to serve as a tourist destination both locally and internationally. Preserving and exploring culture by relying on local strengths of high value to strengthen the identity and personality of the people of Bone Regency as a civilized district.

From the identification of the inhibiting and supporting factors as above, it is a very important and dominant part of the future performance of the Bone Regency Tourism Office. In order to support the vision, mission goals and objectives, the Bone Regency Tourism Office can formulate a development strategy for the Tanjung Palette Tourism Area and other tourism areas in Bone Regency.

\section{Development of Tourist Market Share}

The development of tourist market share is an effort to identify the wants / needs of tourism consumers, determine the products offered, determine prices, promote, and research tourism 
market share. Marketing as a process of exchanging products and values. To have a product that has high selling value, a strategy must be implemented.

The Bone Regency Government continues to strive to increase tourism promotion so that visitors who come from within and outside the Sulawesi Selatab Province continue to increase. The tourism market development strategy can be carried out by means of specific themed promotions in accordance with local culture as an effort to maintain, maintain and preserve as well as re-establish various tourist attractions accompanied by reforms in natural resources, infrastructure, and materials. Promotion must be managed and seen in the form of the tourism industry. Publish leaflets, booklets, guide books and other audio-visual recordings of standard quality, seen from the language layout and promotions that can be sent to various targets / places. Posting various advertisements and articles in various media to international media. Make the direction of each tourist attraction. Improve access, especially overland roads to tourist sites

The management of the development of the tourism market share used to be commonplace, which by the community and other managers interpreted as a matter of course, but over time and it was also realized by managers and the local community, especially the government, that the Tanjung Palette area was a place that could be categorized as a tourist visit area. (DTW) which has natural beauty, the friendliness of its citizens and has a variety of games that will always be visited by domestic and local tourists. So starting from the above statement that the Bone Regency government must think about the demands of business and tourism opportunities by using a marketing strategy in order to have high competitiveness.

\section{Tourism Product Development}

To increase the attractiveness of tourist destinations by creating various tourist products that can increase the flow of tourist visits, including improving the quality of tourism service products by the private sector as a whole, especially in services such as transportation, accommodation, travel arrangements, restaurants and lodging, especially those in the area. Cape Palette. Explore and design attractions and entertainment throughout the year as a tourism calendar by displaying major events, important events, and supporting events such as arts and cultural attractions and centered in the Tanjung Palette Area. Develop communitysourced events, both traditional and modern events or traditional events that are packaged in a modern manner. Environmental planning for the Tanjung Palette Tourism Area which must side with the development of the tourism sector.

\section{Development Through Human Resource Development}

The development strategy through human resource development includes increasing knowledge, understanding, and awareness of all parties regarding tourism issues and efforts to utilize the potential of regional tourism for the welfare of the community. Increased skills and abilities to serve hotel employees and tour service providers in serving the visiting tourists.

\section{Development of Special Tour Packages}

The development of special tour packages is the addition of events in Bone Regency, especially in the Palette Cape area as a form of tourism promotion for visitors. Forms of special tour packages such as events that are always awaited by the community, for example, holding relaxing cycling activities to the Tanjung Palette Tourism Site, trail bike events, and other similar events. The special package is an additional package, the form of the special package is traditional villages, traditional villages, tourist villages and the making of various 
forms of traditional houses into homestays that visitors who come to traditional villages can enjoy or stay in the area.

\section{Develop Quality and Sustainable Tourism Networks and Partnerships}

The strategy that is expected to be able to develop aspects related to the development of the tourism industry, including the development of the reach of the tourism market in planning, should be designed based on regional management and bureau in relation to tourism interests in each sub-district so that it is focused. Working relations with travel agents should be further improved, especially on a local and national scale.

\section{Increasing the Quality and Diversity of Business Products and Tourism Services}

The growth and development of a tourist destination is also influenced by the professionalism of human resources, especially in relation to providing optimal services. For this reason, a strategy is needed to increase human resources including the development of professionalism of human resources involved in the tourism industry in a tiered, sustainable and comprehensive manner by providing training and education. Capacity building and quality of education through secondary, academy, and tertiary education levels as well as certification of all kinds of training to monitor the standards for the quality and quantity of knowledge produced as well as a motivator for achievement Continuously increasing the frequency of non-formal education in the form of awareness campaigns and mass guidance as well as broadening the horizons for related agencies and small entrepreneurs. Upgrading in a planned manner for government officials, especially the staff of the Tourism Office in order to increase professionalism.

\section{Implementation of the Strategy of the Tourism Office in Developing Tanjung Palette Tourism}

In order to implement the strategy that has been formulated based on a comprehensive analysis by the Bone Regency Tourism Office, the next step is to describe the strategy in the form of a program and its budgeting. Based on analysis reports and facts released with consulting service companies for the last 10 years, many have been realized.

The realization of the technical plans that have been formulated has been in progress. However, during the last 5 years there has not been any revision of the technical plan development in question. The development of the technical plan should be revised every year considering that the physical and social conditions of the community have changed a lot every year.

The assumption regarding the obstacle in revising the technical plan is the slow coordination between the Bone Regency Tourism Office Program and the province. According to him, the technical design from the provincial tourism office which is the basis for revision and also it must use consultant services again. Furthermore, it is stated that most of the assets in the Tanjung Palette tourism area are designs from the provincial government such as stages, gazebos accompanied by picture ornaments.

From the results of the interview, it can be seen that the main program carried out by the Bone Regency Tourism Office is a tourist destination development program that focuses on building tourism facilities and infrastructure. Then the program to increase tourism marketing in the form of promotions and exhibitions as well as cultural and arts development programs that are more inclined to training in arts and regional arts performances.

There are several things that hinder the implementation of the program by the Bone Regency Tourism Office related to tourism development. In physical development, it is always collided with budget constraints so that it is done in stages through a priority scale. In 
addition, horizontal conflicts with local communities often occur in terms of land ownership. Such land disputes have been occurring for a long time and are still quite hindering the government from making arrangements around the Tanjung Palette beach. In the promotion section it is also hampered by limitations in the use of technology by the Bone Regency Tourism Office officials to market via the internet. In this case the use of blogs and official websites that are still not up to date and cannot compete with the current development of social media.

Promotion is also done through the website. However, the budgeting has only started this year with the design of an online-based tourism information center (TIC). According to him, currently in the tourist area of Tanjung Palette, the tourist information center in question is already available, but it is still in a simple form so that its use is also ineffective.

To measure the achievement of targets and targets in the development of the Tanjung Palette tourism area, it is very necessary to evaluate the implementation of the technical plans that have been prepared by the District Tourism Office. Bone. However, the implementation of the evaluation in question is running ineffective, even according to the statement of the Head of the Sub-Division of the Program that the evaluation mechanism has never been implemented to date.

Based on the results of this study that the evaluation conducted by the District Tourism Office. Bone in measuring the development of Tanjung Palette does not specifically exist. However, the evaluation carried out in general is in the form of a Government Agency Performance Accountability Report which contains the achievement of targets and performance targets for the overall agency for Bone tourism. In other words, the evaluation of the development of the Tanjung Palette tourism area is contained in the report which is published annually, so that the government can monitor the extent to which targets and targets have been achieved.

Tanjung Palette tourism development basically provides benefits or benefits for tourists, government and local communities. With the presence of tourism, it can provide life or income for local people through the economic benefits obtained from tourist destinations. In addition to the development of infrastructure and recreational facilities, both benefit tourists and the community.

\section{Conclusion}

After analyzing the strengths, weaknesses, threats and opportunities, it can be concluded that the strategies used by the Tourism Office in developing the Tourism Area in Tanjung Palette are developing the tourist market share, developing tourism products, developing human resources, developing tourism packages. Specifically, developing the distribution area for tourist visits and developing quality and sustainable tourism networks and partnerships and increasing the quality and diversity of tourism business products and services.

\section{References}

Amiruddin, H. (2020). Strategy in Promotion E-Tourism Base: Study on Bantaeng Regional Government. Journal La Bisecoman, 1(1), 1-6.

Andersen, T. J. (2013). Short introduction to strategic management. Cambridge University Press.

Boniface, P. (2013). Managing quality cultural tourism. Routledge.

BPS. (2019). Kabupaten Bone Dalam Angka 2019. Cohen, E. (2002). Authenticity, equity and sustainability in tourism. Journal of sustainable tourism, 10(4), 267-276. 
Karppi, I., Kokkonen, M., \& Lähteenmäki-Smith, K. (2001). SWOT-analysis as a basis for regional strategies. Nordregio.

Maté, A., Trujillo, J., \& Mylopoulos, J. (2015). Stress testing strategic goals with SWOT analysis. In International Conference on Conceptual Modeling (pp. 65-78). Springer, Cham.

Richards, G. (2002). Tourism attraction systems: Exploring cultural behavior. Annals of tourism research, 29(4), 1048-1064.

Spillane J.J. (1987). Pariwisata Indonesia Sejarah dan Prospeknya. Kanisius: Yogyakarta.

Wahab, S. (2003). Manajemen Kepariwisataan. Jakarta: Pradnya Paramitha.

Yuwana, D. M. S., \& Setiawan, A. H. (2010). Analisis Permintaan Kunjungan Objek Wisata Kawasan Dataran Tinggi Dieng Kabupaten Banjarnegara. Universitas Diponegoro. 